Bartın Üniversitesi

Eğitim Fakültesi Dergisi

Cilt 6, Sayı 3, s.915-931, Ekim 2017

BARTIN - TÜRKIYE

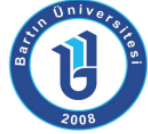

ISSN: 1308-7177
BartinUniversity

Journal of Faculty of Education

Volume 6, Issue3, p. 915-931, October2017

BARTIN - TURKEY

Doi: $10.14686 /$ buefad.311276

\title{
Biyoloji Öğretmen Adaylarının Sosyobilimsel Bir Konudaki Eleştirel Düşünmelerinin Empati Açısından İncelenmesi
}

Esra ÇAKIRLAR ALTUNTAŞ, Arş. Gör., Hacettepe Üniversitesi Eğitim Fakültesi, e-posta:esracakirlar@hacettepe.edu.tr, ORCID: http://orcid.org/0000-0002-3566-8655

Miraç YILMAZ, Yrd. Doç. Dr., Hacettepe Üniversitesi Eğitim Fakültesi, e-posta:mirac@hacettepe.edu.tr, ORCID: http://orcid.org/0000-0003-3200-2767

Salih Levent TURAN, Prof. Dr., Hacettepe Üniversitesi Eğitim Fakültesi, e-posta:letur@hacettepe.edu.tr, ORCID: http://orcid.org/0000-0002-8006-9731

Öz: Karma yöntemin benimsendiği bu araştırma biyoloji öğretmen adaylarının sosyobilimsel bir konuya ilişkin genel eleştirel düşünme ve empati kurarak eleştirel düşünme görüşlerini ve düzeylerini; bu konuya ilişkin karar verme durumlarını incelemeyi amaçlamaktadır. Çalışma, 2015-2016 Bahar Dönemi'nde bir devlet üniversitesinin Biyoloji Eğitimi Anabilim Dalı́nda öğrenim gören 22 öğretmen adayının katıımı ile gerçekleştirilmiştir. íki açık uçlu sorudan oluşan görüş alma formu ile elde edilen verilerin analizinde içerik analizi, dereceli puanlama anahtarı değerlendirmeleri, betimsel ve çıkarımsal istatistikler kullanılmıştır. Araştırma sonucunda, eleştirel düşünmenin empati kurmayı sağlayan ifadeler kullanıldığında derinleştiği; eleştirel düşünme düzeylerinin arttığı; karar verme durumlarının ise değiştiği bulgularına ulaşılmıştır.

Anahtar Kelimeler: eleştirel düşünme, empati, karma yöntem, sosyobilimsel konular

\section{Analysis of Critical Thinkings of Prospective Biology Teachers on a Socio-Scientific Issue in Terms of Empathy}

\begin{abstract}
This mixed method study aims to analyse the general critical thinking and critical thinking by developing empathy levels of prospective biology teachers about socio-scientific issue and their decision making states related to this issue. 22 prospective biology teachers studying in a state university in Spring Term 2015-2016 participated to the study. Content analysis, rubric evaluations, descriptive and inferential statistics were used in the analysis of data collected with two-openended questions. As a result, the findings show that when statements enabling to develop empathy are made, critical thinking deepens, critical thinking levels increase and decision-making states change.
\end{abstract}

Key Words: critical thinking, empathy, mixed method, socio-scientific issues. 


\section{GíRiş}

Çeşitli bilim dallarındaki hızlı gelişmelerin sonuçları toplumları ikilem içeren sosyobilimsel konularla karşı karşıya bırakmaktadır. Sosyobilimsel konular, genellikle etik, ahlaki ya da yasal ikilemler içeren; kesin olarak fikir birliğine varılamayan tartışmalı konular olarak tanımlanmaktadır (Sadler, 2004; Sadler ve Zeidler, 2004). Lee, Abd-El-Khalick ve Choi (2006) ise sosyobilimsel konuları, ahlaki-etik boyutları olan, insan yaşamı üzerinde önemli etkileri olabilecek sosyal çelişkiler olarak tanımlamıştır. Bir konunun sosyobilimsel olarak nitelendirilebilmesi, fen bilimleri konu içerikleri ile ilişkili olmasının yanı sıra konunun sosyal yaşamda anlam ve önem taşımasını gerektirmektedir (Eastwood vd., 2012 aktaran Topçu, 2015). Kolsto (2006) ve Sadler (2003) sorgulama ve karar verme becerilerine sahip sorumluluk sahibi bireylerin topluma kazandırılması için, tek doğrusu olmayan sosyobilimsel konulara programlarda yer vermek gerektiğini bildirmektedirler. Bu durum genetiği değiştirilmiş gıdalar gibi güncel yaşamda karşımıza sıklıkla çıkan sosyobilimsel konuların derslerde ele alınmasını anlamlı kılmaktadır. Bunun yanısıra Paul (1991) eleştirel düşünme gibi üst düzey düşünme becerilerin kazandırılmasında öğrencilerin bu becerileri kullanmasını gerektiren belirli disiplinler ve konu alanlarına yer verilmesini önermektedir. Bunlara dayanılarak bireylerin sosyobilimsel bir konuda etkili karara ulaşabilmesinin, konunun olası etik, ahlaki ve yasal sonuçlarını birlikte değerlendirdiği eleştirel düşünme becerileri ile eleştirel düşünme becerilerinin gelişebilmesi için ise sosyobilimsel konuların programda ele alınmasının gerekliliği ortaya çıkmaktadır.

Epstein'e (1999) göre eleştirel düşünme, bilginin fazla olduğu dünyaya karşı bir savunma şeklidir. Eleştirel düşünme yeteneği, bireylerin tek doğrusu olmayan iddialar ve düşünceler arasında sorgulama yapmasının yanı sıra konuyu analiz edebilmesine de yardımcı olacaktır. Eleştirel düşünebilme ve sağlıklı kararlar alabilme, eğitimli bir bireyde olması beklenen bilişsel becerilerdendir (Gardner, Larsen, Baker, Campbell \& Crosby, 1983). Bu önemli becerinin her yaştaki bireye öğretilebileceği ifade edilmektedir (Demirel, 2012; Walsh ve Paul, 1988). Paul (1991), eleştirel düşünen bireyler yetiştirmek adına örnek eleştirel düşünce öğelerinin, zihin özelliklerinin ve eleştirel düşünme becerilerinin belirli disiplinler ve konu alanları içinde işlenmesinin gerekliliğini; Nosich (2012: s. 23) ise bireylerde eleştirel düşünmenin gelişmesinde empatinin önemini vurgulamaktadır. Cüceloğlu'na (1995) göre bireylerin eleştirel düşünme becerilerini geliştirmedeki etkenlerden biri, başkalarının düşünce süreçlerini inceleyebilmesi, diğer bir ifade ile empati yapabilmesidir.

Empati, bireyin kendisini karşısındakinin yerine koyarak onun duygularını ve düşüncelerini doğru olarak anlama, hissetme ve bu durumu karşısındakine iletme süreci olarak tanımlanmaktadır (Dökmen, 2005). Cotton (1991), zihinde canlandırmayı netleştiren empati becerisinin, duygusal zekânın merkezi bileşenlerinden biri olarak eleştirel düşünmenin ayrılmaz bir parçası olduğunu savunmaktadır. Buna göre empati kurma, eleştirel düşünme becerisine sahip olan bireylerde olması beklenen bir özelliktir. Etkili bir empati için ise düşünmede engel teşkil eden benmerkezcilikten kurtulmanın bir ön şart olduğu belirtilmektedir (Dökmen, 2005; Nosich, 2012, s.23).

Bireylerin sahip olduğu önyargılar ve düşünceler, sosyobilimsel konuları algılama biçimini etkileyebilir. Ancak bireyler, bu konuları algılama biçimlerinin bilişsel modellemelerinden etkilendiğinin farkında olmasalar bile (Paul, 1984) bu farkındalık bireylere eleştirel düşünme becerisi ile kazandırılabilir. Eğitim felsefecileri, eleştirel düşünmenin öğretim sürecinde kullanılabilecek bir seçenek yerine, eğitimin ayrılmaz bir parçası olmasının gerekliliğini vurgulamaktadır (Norris, 1985). 
Günümüzde sınırsız bilgi kaynağı ile karşı karşıya olan bireylerin, toplumda net olarak fikir birliğine varılamayan sosyobilimsel konularla ilgili nitelikli bilgiye ulaşmasında eleştirel düşünme gibi üst düzey düşünme becerileri oldukça önemlidir. Fen eğitiminde sosyobilimsel konuları öğretime dâhil etmenin gerekçesi, sorgulama ve karar verme becerilerine sahip sorumluluk sahibi bireylerin topluma kazandırılması olarak bildirilmiştir (Kolsto, 2006; Sadler, 2003). Sosyobilimsel konular, fen bilimleri disiplinlerinden biri olan biyolojide, son zamanlarda artış gösteren biyoteknoloji ve beraberindeki ürünleri, küresel ısınmayı, enerji kaynaklarının çevre üzerine etkisini, sağlıktaki embriyonik köken hücreleri ve gen terapisi gibi uygulamaları doğrudan insanı ve etkileşimde bulunduğu çevreyi etkileyen birçok konuyu kapsamaktadır. Dolayısıyla sosyobilimsel konular, biyoloji öğretim programında bu ve benzer başlıklarda yer almaktadır. Sosyobilimsel konuları içeren ortaöğretimdeki öğretim programlarında, eleştirel düşünme becerilerinin kazandırılmasının hedeflendiği görülmektedir (Milli Eğitim Bakanlığı [MEB], 2016). Geleceğin karar vericilerinin karşılaşacağı farklı sosyobilimsel konularda etkin karara varabilmeleri, bireylerin derslerde üst düzey düşünme becerilerini geliştirecek öğretim yöntem, teknik ve yaklaşımlarının kullanılması ile mümkün olacaktır.

Üst düzey düşünme becerilerine sahip ve eleştirel düşünebilen öğretmenlerin, günlük hayatta çok sık karşılaşılan sosyobilimsel konuların öğrenciler tarafından nitelikli biçimde anlaşılmasında, bu konulara ilişkin kararların altında yatan eylem ve süreçlerin algılanmasında ve öğrencilerin bilinçli bir şekilde karar vermelerinde önemli rol oynadığı bildirilmektedir (Albe, 2008; Kolsto, 2006). Literatürde öğretmen ve öğretmen adaylarının eleştirel düşünme eğilimlerine ilişkin çalışmalar bulunmasına rağmen, biyoloji öğretmen adaylarına yönelik olan ve sosyobilimsel bir konu ile ilgili eleştirel düşünme becerileri üzerinde empatinin katkısını ortaya koyan çalışmaya rastlanmamıştır. Empatinin eleştirel düşünmeyi etkileyen etmenlerden biri olarak gösterilmesinden yola çıkılarak (Nosich, 2012, s.23), günlük yaşamımızı etkileyen bir sosyobilimsel konunun, olası ahlaki ve yasal sonuçlarının empatiyle birlikte değerlendirildiği eleştirel düşünme becerileri açısından incelenmesi literatüre yeni ve etkili bir bakış açısı sunabilir. Bu çalışmada eleştirel düşünme becerilerinde empatinin etkisini ortaya koymak adına biyoloji öğretmen adaylarının sağlık, bilim, yasalar ve ekonomi gibi açılımlarıyla günlük yaşamlarında sıklıkla karşılarına çıkan ve sonuçları henüz tam olarak bilinemeyen tarımsal uygulamalar ve gıdalardaki genetiği değiştirilmiş ürünlerle ilgili sosyobilimsel konuya ilişkin genel eleştirel düşünme ve empati kurarak eleştirel düşünme düzeylerinin incelenmesi amaçlanmaktadır. Bu araştırmanın sonuç ve önerileri, henüz profosyonel meslek hayatı başlamamış biyoloji öğretmen adaylarının eleştirel düşünme düzeylerinin ve empatinin eleştirel düşünmedeki etkisinin belirlenmesi; sosyobilimsel konulara ilişkin öğrenme ortamlarının iyileştirilmesinin ötesinde, sosyobilimsel konularda sorgulayan, üst düzey düşünme becerilerine, ahlaki ve etik değerlere sahip öğrenciler yetiştirilmesine katkılar sağlanması bakımından önemlidir.

\section{1.Çalışmanın Amacı}

Bu çalışma ile biyoloji öğretmen adaylarının, sonuçları tam olarak kestirilemeyen genetiği değiştirilmiş ürünlerin tarımsal uygulamalarıyla ilgili sosyobilimsel konuya ilişkin eleştirel düşünme ve aynı sorunun empati kurarak sorulması sonucunda belirttikleri görüşlerinin, eleştirel düşünme ve empati kurarak eleştirel düşünme düzeylerinin, bu düzeyler arasında fark olup olmadığının ve karar verme durumlarının incelenmesi amaçlanmıştır. Bu amaç altında incelenecek olan araştırma alt problemleri şöyle sıralanabilir:

1. Biyoloji öğretmen adaylarının genetiği değiştirilmiş ürünlerin tarımsal uygulamalarına ilişkin sosyobilimsel konudaki eleştirel düşünme görüşleri ve aynı sorunun empati kurarak sorulması sonucunda belirttikleri görüşleri nasıldır? 
2. Biyoloji öğretmen adaylarının genetiği değiştirilmiş ürünlerin tarımsal uygulamalarına ilişkin sosyobilimsel konudaki eleştirel düşünme düzeyleri ve empati kurarak eleştirel düşünme düzeyleri nedir?

3. Biyoloji öğretmen adaylarının genetiği değiştirilmiş ürünlerin tarımsal uygulamalarına ilişkin sosyobilimsel konudaki eleştirel düşünme ve empati kurarak eleştirel düşünme düzeyleri arasında fark var mıdır?

4. Biyoloji öğretmen adaylarının genetiği değiştirilmiş ürünlerin tarımsal uygulamalarına ilişkin sosyobilimsel konudaki onay durumları, eleştirel düşünme ve empati kurarak eleştirel düşünme görüş sorularında değişiklik göstermekte midir?

\section{YÖNTEM}

\subsection{Araştırma Modeli}

Araştırma nitel ve nicel araştırma yöntemlerinin birlikte kullanıldığı bir karma yöntem araştırmasıdır. Karma yöntem araştırmaları, sosyal bilimlerde özellikle eğitim bilimlerinde disiplinler arası araştırmaların gerçekleşmesi ile araştırılan olayın çeşitli yönlerinin açığa kavuşmasına yardımcı olmaktadır (Creswell ve Garrett, 2008). Bu çalışmada öğrenci görüşleri nitel olarak içerik analizine tabii tutulacak ve dereceli puanlama anahtarı ile verdikleri cevaplar puanlanarak nicel olarak değerlendirilecek ve eleştirel düşünme düzeyleri arasında nicel olarak fark olup olmadığı araştırılarak, onay verme durumları açısından tartışılacaktır. Araştırma çok yönlü olduğundan ve farklı araştırma yolları kullanıldığından karma yöntemin seçilmesine karar verilmiştir.

\section{2. Çalışma Grubu}

Araştırmanın çalışma grubunu 2015-2016 Bahar Dönemi'nde Ankara'da bulunan bir devlet üniversitesinin Biyoloji Eğitimi lisans programında öğrenim görmekte olan öğretmen adayları arasından amaçlı örnekleme yöntemlerinden ölçüt örnekleme ile seçilen ve çalışmaya gönüllü olarak katılmak isteyen 22 biyoloji öğretmen adayı oluşturmaktadır. Ölçüt örnekleme yönteminde kıstas, öğretmen adaylarının yöneltilen görüş sorularında yer alan genetiği değiştirilmiş ürünlerin, bu ürünlerin tarımsal uygulamalarını bu uygulamaların çevresel etkilerine ilişkin bilgileri edindiği "Çevre Koruma ile Moleküler Biyoloji derslerini almış olmaları" şeklinde belirlenmiştir. Çalışma grubunun belirlenmesinin bu ölçüte göre yapılmasının sebebi sağlık, bilim, yasalar ve ekonomi gibi açılımlarıyla oldukça geniş bir yelpazede tartışılan ve sonuçları henüz tam olarak bilinemeyen tarımsal uygulamalar ve gıdalardaki genetiği değiştirilmiş ürünlerle ilgili sosyobilimsel konuya ilişkin mümkün olduğunca fazla bilgi ve görüşe sahip olmalarıdır. Böylelikle araştırılmak istenen alt problemlerin daha verimli bir biçimde incelenebilmesi mümkün olabilecektir. Çalışma grubuna ilişkin betimsel istatistikler Tablo 1'de verilmiştir.

Tablo 1

Biyoloji Öğretmen Adaylarının Kişisel Bilgilerine ilişskin Betimsel Istatistikler

\begin{tabular}{llll}
\hline \multirow{2}{*}{ Cinsiyet } & & $\mathbf{f}$ & $\%$ \\
& Kadın & 21 & 95.5 \\
Sınıf Düzeyi & Erkek & 1 & 4.5 \\
& 4. Sınıf & 14 & 63.6 \\
Akademik Başarı & 5. Sınıf & 8 & 36.4 \\
& $2.00-2.99$ & 7 & 31.8 \\
& $3.00-4.00$ & 15 & 68.2 \\
\hline
\end{tabular}

Tablo 1'de görüldüğg̈ gibi araştırmaya \%95.5 $(f=21)$ kadın, \% $4.5(f=1)$ erkek olmak üzere 22 biyoloji öğretmen adayı katılmıştır. Katılımcı biyoloji öğretmen adayları, ağırıılı olarak 
4. sınıfta öğrenim görmektedir ( $\% 63.6, f=14$ ) ve $3.00-4.00$ arasında akademik başarıya sahiptir (\%68.2).

\subsection{Veri Toplama Aracı ve Uygulama}

Araştırmada biyoloji öğretmen adaylarının sosyobilimsel bir konudaki eleştirel düşünme düzeylerine ve aynı sorunun empati kurarak eleştirel düşünme düzeylerine yönelik iki açık uçlu görüş sorunun yer aldığı görüş alma formu kullanılmıştır. Görüş alma formundaki ilk soru "Tarım arazilerinde genetiği değiştirilmiş ürünlerin yetiştirilmesini onaylıyor musunuz? Bu konudaki görüşlerinizi ve nedenlerini açıklayınız." şeklinde eleştirel düşünmeye yönelik iken, ikinci soru "Verimli bir araziniz olduğunu düşünün. Kendi arazinizde genetiği değiştirilmiş ürünlerin yetiştirilmesine onay verir miydiniz? Bu konudaki görüşlerinizi ve nedenlerini açıklayınız." empati kurarak eleştirel düşünmeye yöneliktir. Öğretmen adaylarından bu sorulara ilişkin görüşlerini içeren bir metin yazmaları istenmiştir ve her bir soru için 40 dakika olmak üzere toplam 80 dakika süre tanınmıştır.

Görüş alma formunda, incelenmek istenen olgunun esnek bir yaklaşımla ele alınmasını sağlayan açık uçlu sorular kullanılmıştır. Görüş alma formunun kapsam geçerliği için alanında uzman öğretim üyelerinin görüşlerine başvurulmuştur. Nitel araştırmalarda geçerlik güvenirliğe göre daha önceliklidir (Yıldırım \& Şimşek, 2011: s. 256). Bu nedenle veri toplama aşamasında geçerliği sağlayabilmek adına araştırma alanına yakınlık ve elde edilen verilerin ayrıntılı olarak rapor edilmesine dikkat edilmiştir. Ayrıca dış geçerliği sağlayabilmek için amaçlı örnekleme yöntemi tercih edilmiştir.

\subsubsection{Genetiği Değiştirilmiş Ürünlere ilişskin Eleştirel Düşünme Dereceli Puanlama} Anahtarı

Analitik dereceli puanlama anahtarı, örneklemin başarısının çeşitli boyutlarındaki başarı düzeyleri hakkında bilgi veren puanlama aracı olarak tanımlanmaktadır (Kutlu, Doğan ve Karakaya, 2009). Araştırmacılar tarafından çalışmada elde edilen nitel verileri sayısallaştırmak adına "Genetiği Değiştirilmiş Ürünlere illişkin Eleştirel Düşünme Dereceli Puanlama Anahtarı", 1990 yılında Amerikan Felsefe Derneği'nin düzenlediği Delphi Projesi olarak ortaya çıkan ve literatürde farklı kültürlere uyarlanma aşamasında madde ve boyut farklılaşmaları görülen Kaliforniya Eleştirel Düşünme Eğilimi Ölçeği'nin (CCTDI) geliştirilmesi aşamalarında ortaya çıkan kuramsal alt yapıdan yararlanılarak hazırlanmıştır. Kaliforniya Eleştirel Düşünme Eğilimi Ölçeği, farklı düşünceleri değerlendirme eğilimini ölçen "Doğruyu arama", kendi düşüncelerinin yanında karşısındaki bireylerin düşüncelerini dikkate almayı ölçen "Açık fikirlilik", potansiyel sorunlar karşısında akıl yürütme becerilerini ölçen "Analitiklik", bilgiye dayalı karar verme becerilerini ölçen "Sistematiklik", akıl yürütme sürecine duyduğu güveni ölçen "Kendine güven", bireyin yeni bilgiler edinme eğilimini belirleyen "Meraklılı" ve bilişsel gelişimi ölçen "Olgunluk" olmak üzere 7 alt boyuttan oluşmaktadır (Kökdemir, 2003).

Hazırlanan Genetiği Değiştirilmiş Ürünlere İlişkin Eleştirel Düşünme Dereceli Puanlama Anahtarına ait 3 boyut araştırmacılar tarafından "Bilgi", "Empati" ve "Mantık" olarak isimlendirilmiştir. "Bilgi" boyutu, "Sistematiklik" boyutunun kuramsal temelleri göz önünde bulundurularak; genetiği değiştirilmiş ürünlerin üretim amaçlarına, bu ürünlerin ilişkili olduğu alanlara, olası yarar ve zararlarına ilişkin ölçütleri içine alan genetiği değiştirilmiş ürünlerin tarımsal uygulamalarına ilişkin temel bilgiler ile karar verme becerilerini içermektedir. "Açık fikirlilik" boyutunun kuramsal temelleri doğrultusunda hazırlanan "Empati" boyutu kişinin kendisinin ve karşı görüşün düşüncelerini dikkate alma, olayları değerlendirme biçimini ölçmektedir. "Doğruyu arama" boyutunun kuramsal temellinden yola çıkarak hazırlanan dereceli puanlama anahtarının "Mantık" boyutunda ise görüşlerin ifade biçimi ve görüşlerin niteliğini ele alan ölçütler yer almaktadır. 
Genetiği Değiştirilmiş Ürünlere Iliş̧kin Eleştirel Düşünme Dereceli Puanlama Anahtarının kapsam geçerliği, moleküler genetik ve dereceli puanlama hazırlama alanlarında uzman iki öğretim üyesinin görüşleri ile sağlanmış, güvenirliği için ise aynı soruya ilişkin iki ölçüm arasındaki Pearson Korelasyon katsayısına ile Miles ve Huberman'ın (1994) uzlaşma oranı hesaplamalarına (interrate agreement) bakılmıştır. İki ölçüm arasındaki Pearson Korelasyon katsayısı 0,97, uzlaşma oranı ise \%91 olarak belirlenmiştir. Bu sonuçlar doğrultusunda dereceli puanlama anahtarı geçerli ve güvenilir olduğu söylenebilir.

Genetiği Değiştirilmiş Ürünlere İlişkin Eleştirel Düşünme Eğilimi Dereceli Puanlama Anahtarına ilişkin düzey tanımları belirlenen ölçütler doğrultusunda "oldukça başarılı" üç puan, "kabul edilebilir" iki puan, "yetersiz" bir puan olacak şekilde belirlenmiştir. Görüş alma formunda yer alan görüşler ise belirlenen ölçüt tanımlarına uygun olarak puanlanmıştır.

Genetiği Değiştirilmiş Ürünlere İlişkin Eleştirel Düşünme Eğilimi Dereceli Puanlama Anahtarının "Bilgi" boyutundan en az 5-15, "Empati" ve "Mantık" boyutlarından ise 1-3 arasında olacak şekilde toplamda alınabilecek maksimum puan 21 iken, alınabilecek minimum puan 7'dir. Genetiği Değiştirilmiş Ürünlere İlişkin Eleştirel Düşünme Eğilimi Dereceli Puanlama Anahtarının "Bilgi" boyutunda orta değer 10, "Empati" boyutunda 2 ve "Mantık" boyutunda 2 olmak üzere genel orta değer 14 olarak belirlenmiştir.

\subsection{Veri Analizi}

Biyoloji öğretmen adaylarının görüş alma formundaki sorulara ilişkin görüşleri öncelikle içerik analizine tabii tutulmuş, ikinci aşamada ise geliştirilen Genetiği Değiştirilmiş Ürünlere Ilişkin Eleştirel Düşünme Dereceli Puanlama Anahtarı ile nitel veriler sayısallaştırılarak üç boyutta (bilgi, empati, mantık boyutları) değerlendirilmiştir. Parametrik bir test olan ve ortalama puanlar arasında fark olup olmadığını belirlemek için yapılan ilişkili örneklemler için ttestine ilişkin normallik testi, örneklem sayısının 50'nin altında olması nedeniyle Shapiro-Wilk ile test edilmiştir (Tablo 2) (Büyüköztürk, 2014, s.42).

Tablo 2

ilişkili Örneklemler Için T-Testine ilişkin Normallik Testi

\begin{tabular}{|c|c|c|c|}
\hline \multicolumn{4}{|c|}{ Shapiro-Wilk Normallik Testi } \\
\hline Ölçüm & İstatistik & sd & $\mathbf{P}$ \\
\hline $\begin{array}{l}\text { 1.Görüş Sorusu (Tarım arazilerinde genetiği değiştirilmiş } \\
\text { ürünlerin yetiştirilmesini onaylıyor musunuz? Bu } \\
\text { konudaki görüşlerinizi ve nedenlerini açıklayınız.) }\end{array}$ & .933 & 22 & .140 \\
\hline $\begin{array}{l}\text { 2.Görüş Sorusu (Verimli bir araziniz olduğunu düşünün. } \\
\text { Kendi arazinizde genetiği değiştirilmiş ürünlerin } \\
\text { yetiştirilmesine onay verir miydiniz? Bu konudaki } \\
\text { görüşlerinizi ve nedenlerini açıklayınız.) }\end{array}$ & .942 & 22 & .221 \\
\hline
\end{tabular}

Tablo 2'de verilen birinci ve ikinci görüş sorularına ilişkin puanlar normal dağılım göstermektedir ( $p>0.05)$.

Yapılan içerik analizinde temel amaç, toplanan verileri açıklayabilecek kavramlara ulaşmaktır. Bu nedenle birbirine benzeyen ifadeler belirli temalar atında toplanmıştır. Verilerin kodlanmasında, öncelikle elde edilen veriler araştırmacılar tarafından incelenmiş ve anlamlı olan kısımlardan kodlar oluşturulmuştur. Daha sonra belirlenen kodları kapsayacak temalar atanmıştır. Ayrıca, yapılan analizin okuyucu tarafından anlamlandırılabilmesi için bulgular kısmında öğretmen adaylarının görüşlerinden doğrudan alıntılara yer verilmiştir. Okuyucuya sunulan doğrudan alıntılarda, öğretmen adaylarının isim bilgileri kısaltmalar şeklinde gösterilmiştir. Ö harfi, öğretmen adayını, yanındaki sayı ise öğretmen adayının isim bilgilerini temsil etmektedir. 
Biyoloji öğretmen adaylarının sosyobilimsel konudaki eleştirel düşünme ve empati kurarak eleştirel düşünmeye ilişkin karar verme durumları verilen cevaplara göre belirlenen kategoriler oluşturularak değerlendirilmiştir. Buna göre genetiği değiştirilmiş ürünlere ilişkin eleştirel düşünme sonucunda ulaştıkları karar verme durumları onay, şartlı onay, şartlı ret ve ret olmak üzere 4 kategoride incelenmiştir. Yapılan istatistiki analizde öğretmen adaylarının karar verme durumları, karara ilişkin onayını bir koşula dayandırıyorsa "şartlı onay", koşulsuz onay veriyorsa "onay", ret etme durumunu bir koşula dayandırarak ifade ediyorsa "şartlı ret", koşulsuz olarak ret ediyorsa "ret" şeklinde kategorize edilmiştir.

\section{BULGULAR}

\subsection{Biyoloji Öğretmen Adaylarının Genetiği Değiştirilmiş Ürünlerin Tarımsal Uygulamalarına İlişkin Görüşleri}

Bu başlık altında biyoloji öğretmen adaylarının genetiği değiştirilmiş ürünlerin tarımsal uygulamaları sosyobilimsel konusuna ilişkin eleştirel düşünme sorusu ve aynı sorunun empati kurarak sorulması sonucunda belirttikleri görüşler içerik analizine tabi tutulmuştur ve bu görüşlere ilişkin içerik analizi Tablo 3'te verilmiştir.

Tablo 3

Genetiği Değiştirilmiş Ürünlerin Tarımsal Uygulamalarına ilişkin Görüşler

\begin{tabular}{|c|c|c|c|c|c|c|c|c|}
\hline \multicolumn{5}{|c|}{$\begin{array}{l}\text { Sosyobilimsel Konudaki Eleştirel Düşünme } \\
\text { Sorusuna İlişkin Görüşler }\end{array}$} & \multicolumn{2}{|l|}{$\begin{array}{l}\text { Sosyobilimsel Konudaki } \\
\text { Eleştirel Düşünme Sorusuna } \\
\text { illişkin Görüşler }\end{array}$} & \multicolumn{2}{|c|}{ Kurarak } \\
\hline$\stackrel{\mathbb{Z}}{\mathscr{\varrho}}$ & $\begin{array}{l}\text { 우 } \\
\text { - }\end{array}$ & 4 & $\underset{\leftarrow}{\stackrel{\varepsilon}{\frac{\pi}{2}}}$ & வீ & $\begin{array}{l}\text { ठ } \\
\text { o }\end{array}$ & 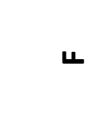 & $\underset{\leftarrow}{\frac{E}{20}}$ & dீ \\
\hline \multirow{3}{*}{$\begin{array}{l}\text { 兰 } \\
\text { 롶 }\end{array}$} & $\begin{array}{l}\text { Ülkemizdeki kullanım } \\
\text { alanlarını belirtme }\end{array}$ & 7 & & & & & \multirow{3}{*}{2} & \multirow{3}{*}{1.6} \\
\hline & $\begin{array}{l}\text { Ülkemizdeki hukuki } \\
\text { uygulamaları belirtme }\end{array}$ & 6 & 15 & 11.3 & $\begin{array}{l}\text { Ülkemizdeki hukuki } \\
\text { uygulamaları belirtme }\end{array}$ & 2 & & \\
\hline & $\begin{array}{l}\text { Uygulamadaki teknik ve } \\
\text { stratejilerden söz etme }\end{array}$ & 2 & & & & & & \\
\hline \multirow{8}{*}{$\begin{array}{l}\overline{\bar{\varepsilon}} \\
\overline{\check{O}} \\
\overline{0} \\
\overline{\mathrm{D}}\end{array}$} & Raf ömrünün uzaması & 6 & \multirow{8}{*}{49} & \multirow{8}{*}{37.1} & Raf ömrünün uzaması & 3 & \multirow{8}{*}{30} & \multirow{8}{*}{24.6} \\
\hline & $\begin{array}{l}\text { Birim alandan alınan } \\
\text { ürün miktarında artış }\end{array}$ & 12 & & & $\begin{array}{l}\text { Birim alandan alınan ürün } \\
\text { miktarında artış }\end{array}$ & 11 & & \\
\hline & $\begin{array}{l}\text { Zor koşullara karşı } \\
\text { dayanıklılık }\end{array}$ & 4 & & & $\begin{array}{l}\text { Zor koşullara karşı } \\
\text { dayanıklılık }\end{array}$ & 2 & & \\
\hline & Tohumda dışa bağımlılık & 7 & & & Tohumda dışa bağımlılık & 5 & & \\
\hline & $\begin{array}{l}\text { Mevsiminden önce ürün } \\
\text { yetişmesi }\end{array}$ & 7 & & & & & & \\
\hline & Ürünlerin albenili olması & 4 & & & Ürünlerin albenili olması & 3 & & \\
\hline & Üretimin pahalı olması & 2 & & & Üretimin pahalı olması & 4 & & \\
\hline & $\begin{array}{l}\text { Artan nüfusun besin } \\
\text { ihtiyacının karşılanması }\end{array}$ & 7 & & & $\begin{array}{l}\text { Artan nüfusun besin } \\
\text { ihtiyacının karşılanması }\end{array}$ & 2 & & \\
\hline \multirow{5}{*}{$\begin{array}{l}\frac{\overline{0}}{0} \\
\frac{2}{4}\end{array}$} & $\begin{array}{l}\text { Toprak kirliliğine yol } \\
\text { açması }\end{array}$ & 10 & \multirow{5}{*}{52} & \multirow{5}{*}{39.4} & Toprak kirliliğine yol açması & 7 & \multirow{5}{*}{47} & \multirow{5}{*}{38.5} \\
\hline & Su kirliliğine yol açması & 2 & & & Su kirliliğine yol açması & 4 & & \\
\hline & $\begin{array}{l}\text { Hava kirliliğine yol } \\
\text { açması }\end{array}$ & 1 & & & & & & \\
\hline & $\begin{array}{l}\text { Biyolojik çeşitliliğin } \\
\text { olumsuz etkilenmesi } \\
\end{array}$ & 16 & & & $\begin{array}{l}\text { Biyolojik çeşitliliğin olumsuz } \\
\text { etkilenmesi }\end{array}$ & 16 & & \\
\hline & $\begin{array}{l}\text { Tarım arazilerinin } \\
\text { verimliliğinin azalması }\end{array}$ & 6 & & & $\begin{array}{l}\text { Tarım arazilerinin } \\
\text { verimliliğinin azalması }\end{array}$ & 10 & & \\
\hline
\end{tabular}




\begin{tabular}{|c|c|c|c|c|c|c|c|c|}
\hline & $\begin{array}{l}\text { Herbisite/Insektisite } \\
\text { karşı direnç }\end{array}$ & 6 & & & $\begin{array}{l}\text { Herbisite/İnsektisite karşı } \\
\text { direnç }\end{array}$ & 3 & & \\
\hline & $\begin{array}{l}\text { Gen kaçışlarının } \\
\text { yaşanması }\end{array}$ & 11 & & & Gen kaçışlarının yaşanması & 7 & & \\
\hline \multirow{2}{*}{ 兰 } & $\begin{array}{l}\text { Amaç dışı kullanıma } \\
\text { yönelim }\end{array}$ & 1 & \multirow{2}{*}{3} & \multirow{2}{*}{2.3} & Amaç dışı kullanıma yönelim & 1 & \multirow{2}{*}{3} & \multirow{2}{*}{2.5} \\
\hline & $\begin{array}{l}\text { Tüketici bilme hakkının } \\
\text { ihlali }\end{array}$ & 2 & & & Tüketici bilme hakkının ihlali & 2 & & \\
\hline \multirow{5}{*}{ 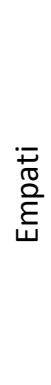 } & $\begin{array}{l}\text { Toplum sağlığının } \\
\text { etkilenmesi }\end{array}$ & 10 & \multirow{5}{*}{13} & \multirow{5}{*}{9.9} & $\begin{array}{l}\text { Toplum sağlığının } \\
\text { etkilenmesi }\end{array}$ & 13 & \multirow{5}{*}{40} & \multirow{5}{*}{32.8} \\
\hline & $\begin{array}{l}\text { Hayvan sağlığının } \\
\text { etkilenmesi }\end{array}$ & 3 & & & $\begin{array}{l}\text { Hayvan sağlığının } \\
\text { etkilenmesi }\end{array}$ & 7 & & \\
\hline & & & & & $\begin{array}{l}\text { Gelecek kuşakların olumsuz } \\
\text { etkilenmesi }\end{array}$ & 10 & & \\
\hline & & & & & $\begin{array}{l}\text { Kendi ve ailesinin sağ|ığının } \\
\text { etkilenmesi }\end{array}$ & 8 & & \\
\hline & & & & & Verimsiz arazinin kullanı & 2 & & \\
\hline
\end{tabular}

Tablo 3'te, biyoloji öğretmen adaylarının genetiği değiştirilmiş ürünlerin tarımsal uygulamalarına ilişkin görüşlerinin içerik analizinde, her iki görüş sorusuna yönelik hukuk, ekonomi, ekoloji, etik ve empati olmak üzere aynı temalara yer verildiği görülmüştür.

Kodların dağııımına bakıldığında, hukuk temasına ilişkin eleştirel düşünme sorusu için 3 kod (hukuk teması altında kullanım alanları, hukuki uygulamalar, uygulamadaki teknik ve stratejileri) ve \%9.4 dağılım; empati kurarak eleştirel düşünmeye dair görüş sorusunda ise 1 kod (hukuki uygulamalar) ve \%1.6 oranında bir dağılım olduğu görülmüştür. Hukuk temasına ait eleştirel düşünme ve empati kurarak eleştirel düşünme sorularına ilişkin görüşleri vurgulayan örnek ifadeler sırası ile aşağıdaki gibidir: (Ö: Öğretmen adayı)

Ö16: "Türkiye'de genetiği değiştirilmiş ürün satışı yasal olmamakla birlikte bilinen 23 yemde genetiği değiştirilmiş ürün kullanılıyor. Ayrıca yasal olmayan yollarla pek çok ürün genetiği değiştirilmiş ürün yetiştiren ülkelerden gelir. Hal böyle olunca genetiği değiştirilmiş ürün üretmesek de gelen ürünlerin GDO’suz olma ihtimali yoktur."

Ö6: "Artan nüfus yoğunluğunun yiyecek ihtiyacının karşılaması için ortaya çıkan genetiği değiştirilmiş ürünlerin sağlıklı bir şekilde üretilmesi için ülkemizin ya da ülkelerin kendine ait birimleri olmalı ki bu konuyla ilgili çalışmalarını dışa bağımlı olmadan yapabilsinler. Ülkemize giren yiyecekler hukuki düzenlemelerle gümrük kontrollerinde hassasiyetle kontrol edilmelidir."

Ekonomi temasına ilişkin olarak eleştirel düşünmeye yönelik görüş sorusunda 8 kod (raf ömrünün uzaması, birim alandan alınan ürün miktarındaki artış, zor koşullara karşı dayanıklı ürünler, tohumda dışa bağımlıık, mevsiminden önce ürün yetiştirilebilmesi, ürünlerin daha albenili olması, üretimlerinin pahalı olması ve artan nüfusun besin ihtiyacının karşılanması) ve \%30.8 dağılım; empati kurarak eleştirel düşünmeye ilişkin görüş sorusunda ise 7 kod (raf ömrünün uzaması, birim alandan alınan ürün miktarındaki artış, zor koşullara karşı dayanıklı ürünler, tohumda dışa bağımlııı, ürünlerin daha albenili olması, artan nüfusun besin ihtiyacının karşılanması ve istihdamın sağlanması) ve \%24.6 oranında bir dağılım olduğu görülmüştür. Ekonomi temasına ait eleştirel düşünme ve empati kurarak eleştirel düşünme sorularına ilişkin görüşleri vurgulayan örnek ifadeler sırasıyla aşağıdaki gibidir:

Ö15: "Genetiği değiştirilmiş ürünlerin tohum üretimi sınırlıdır. Tohum toprağa ekildiğinde yeniden ürün vermeyecek şekilde değiştirilmiştir. Bunun nedeni de tarımla uğraşanları yani ülkeleri tohum açısından kendilerine bağımlı hale getirmeyi amaçlamalarıdır." 
Ö3: "...Açlığa çözüm olarak ortaya çıkan genetiği değiştirilmiş ürünlerin raf ömrü uzundur, herbisitlere karşı dirençlidir. Ürün verimi yüksektir. Birçok besin maddesi daha kısa zamanda ve yüksek verimle elde edilir."

Ekoloji temasında eleştirel düşünme sorusunda belirttikleri görüşlerinde 7 kod (toprak ve suyun yapısını bozması, hava kirliliği yaratması, biyolojik çeşitliliğin olumsuz etkilenmesi, tarım arazilerinin verimliliğinin azalması, herbisit ve insektisitlere karşı direnç oluşması, gen kaçışlarının yaşanması) ve \%32.7 dağılım; empati kurarak eleştirel düşünmeye dair ikinci görüş sorusunda ise 6 kod (toprak ve suyun yapısını bozması, biyolojik çeşitliliğin olumsuz etkilenmesi, tarım arazilerinin verimliliğinin azalması, herbisit ve insektisitlere karşı direnç oluşması, gen kaçışlarının yaşanması ) ve \%38.5 oranında bir dağılım olduğu görülmüştür. Ekoloji temasına ait eleştirel düşünme ve empati kurarak eleştirel düşünme sorularına ilişkin görüşleri vurgulayan örnek ifadeler sırasıyla aşağıdaki gibidir:

Ö18: "Genetiği değiştirilmiş ürünlerin yetiştirilmesi, o toprakta yaşayan diğer organizmaların da yetiştirilen ürüne karşı uyumunu tetikleyecektir. Gen kaçışları yeni bir direnç oluşumu anlamına gelir. Ayrıca toprak, ürünler zarar görmesin diye ilaçlanıyor ve dolayısıyla aşırı toksik madde birikimine maruz kalıyor. Bu durum toprakta yaşayan yararlı organizmalar için bir tehdittir."

Ö13: "...Genetiği değiştirilmiş ürünlerin hayatımıza girmesi belki de en çok tarım arazilerini etkilemektedir. Daha az maliyetle daha çok ürün elde etmek için tercih edilen genetiği değiştirilmiş ürünler, genetik çeşitliliğin değişmesine ve biyolojik çeşitliliğin yok olmasına neden olmaktadır."

Etik temasına ilişkin olarak eleştirel düşünme sorusundaki görüşlerde 2 kod ve \%1.8 dağılım; empati kurarak eleştirel düşünme görüş sorusunda ise 2 kod ve $\% 2.5$ oranında bir dağılım olduğu görülmüştür. Biyoloji öğretmen adayları her iki görüş sorusunda da etik temasına ilişkin genetiği değiştirilmiş ürünlerin amaç dışı kullanıma yönelim riskleri ve tüketicinin bilme hakkının ihlal edilebileceği şeklinde kodlanabilen görüşler bildirmişlerdir. Etik temasına ait eleştirel düşünme ve empati kurarak eleştirel düşünme sorularına ilişkin görüşleri vurgulayan örnek ifadeler sırasıyla aşağıdaki gibidir:

Ö10: "Genetiği değiştirilmiş ürünler konusunda insanların bilinçlendirilmesi gerektiğini düşünüyorum. Bu ürünlerin satışı yapılsa bile üstünde bir bilgi etiketi olmalı ve alıp almamak insanların tercihine bırakılmalıdır."

Ö14: "Daha kısa sürede daha fazla ürün elde etmek isterken istemediğimiz ürünlerle de karşılaşabiliriz. Gelişen teknoloji ile birlikte bilim insanları genlerle istedikleri gibi değişiklikler yapabiliyor. Bu da genetiği değiştirilmiş ürünlerin biyolojik silah olarak kullanılmasına neden olabilir."

Empati teması altında eleştirel düşünme sorusuna belirtilen görüşlerde 2 kod ve \%25.1 dağılım; empati kurarak eleştirel düşünmeye yönelik görüş sorusunda ise 5 kod ve \%32.8 oranında bir dağılım olduğu görülmüştür. Biyoloji öğretmen adaylarının genel eleştirel düşünme düzeylerine ilişkin görüş sorusu altında belirtilen iki kod toplum sağlığının etkilenmesi ve hayvan sağlığının etkilenmesi şeklindedir. Ancak empati kurarak eleştirel düşünme eğilimine yönelik görüş sorusunda kendi ve ailesinin sağlığının etkilenmesi, toplum sağlığının etkilenmesi, gelecek kuşakların olumsuz etkilenmesi, hayvan sağı̆ı̆ının etkilenmesi, verimsiz arazilerimizin kullanılması gibi daha fazla kod altında toplanabilen görüşler ifade edilmiştir. Empati temasına ait eleştirel düşünme ve empati kurarak eleştirel düşünme sorularına ilişkin görüşleri vurgulayan örnek ifadeler sırasıyla aşağıdaki gibidir:

Ö9: "Genetiği değiştirilmiş ürünlerin hayvan ve insan sağlığına nasıl etki ettiği tam olarak bilinmemekle birlikte hayvanlar üzerinde yapılan deneylerde hayvanların kansere 
yakalanma riskinin arttığı ve buna bağlı gelişim geriliği görüldüğü tespit edilmiştir. Bu sonuçların insan sağlığını da doğrudan etkilediği şüphesizdir."

Ö8: "Genetiği değiştirilmiş ürünlerin bana ve diğer insanlara vereceği zararları düşünürken bu ürünleri verimli toprağımda yetiştirmek korkunç olur. Genetiği değiştirilmiş ürünlerin yetiştirildiği arazilere yakın yaşayan insanlarda çeşitli hastalıklar ortaya çıkarken, bu ürünleri tüketerek kendimize nasıl zarar verdiğimizin farkında değiliz. Belki etkileri hemen gözlenmeyecek ancak ileriki kuşaklara genlerimizde neleri miras bırakıyoruz insanların oturup bir düşünmesi gerek."

\subsection{Biyoloji Öğretmen Adaylarının Genetiği Değiştirilmiş Ürünlere iliş̧in Eleştirel Düşünme ve Empati Kurarak Eleştirel Düşünme Düzeyleri}

Araştırmada biyoloji öğretmen adaylarının her iki görüş sorusuna yönelik ifadeleri, Genetiği Değiştirilmiş Ürünlere ilişskin Eleştirel Düşünme Dereceli Puanlama Anahtarı ile puanlanarak nicelleştirilmiş ve düzeyleri belirlenmiştir (Tablo 4).

Tablo 4

Biyoloji Öğretmen Adaylarının Dereceli Puanlama Anahtarının Boyutlarına Göre Eleştirel Düşünme ve Empati Kurarak Eleştirel Düşünme Düzeyleri

\section{Kategori}

1. Görüş Sorusu (Tarım arazilerinde genetiği değiştirilmiş ürünlerin yetiştirilmesini onaylıyor musunuz? Bu konudaki görüşlerinizi ve nedenlerini açıklayınız.)

2. Görüş Sorusu (Verimli bir araziniz olduğunu düşünün. Kendi arazinizde genetiği değiştirilmiş ürünlerin yetiştirilmesine onay verir miydiniz? Bu konudaki görüşlerinizi ve nedenlerini açıklayınız.)

Tablo 4 incelendiğinde biyoloji öğretmen adaylarının, genetiği değiştirilmiş ürünlerin tarımsal uygulamaları ile ilgili eleştirel düşünme düzeyini genel çerçevede incelemeyi hedefleyen birinci görüş sorusu için Genetiği Değiştirilmiş Ürünlere iliş̧kin Eleştirel Düşünme Dereceli Puanlama Anahtarından aldıkları eleştirel düşünme ortalama puanlarının 13.9 olduğu ve orta düzeyde nitelendirilebileceği tespit edilmiştir. Bu görüş sorusu için Genetiği Değiştirilmiş Ürünlere İlişkin Eleştirel Düşünme Dereceli Puanlama Anahtarının alt boyutundan aldıkları puanlar "bilgi" alt boyutunda 9.9, "empati" alt boyutunda 1.8 düzeyinde ve "mantık" alt boyutunda ise 2.2 düzeyindedir. Bilgi ve empati boyutları orta değerin altında, mantık boyutu ise orta değerin üzerinde olduğu belirlenmiştir.

Tablo 4'e göre biyoloji öğretmen adaylarının genetiği değiştirilmiş ürünlerin tarımsal uygulamaları ile ilgili empati kurarak eleştirel düşünme düzeyini incelemeyi hedefleyen 2. görüş sorusu için Genetiği Değiştirilmiş Ürünlere illişkin Eleştirel Düşünme Dereceli Puanlama Anahtarından aldıkları eleştirel düşünme puan ortalamasının 15.3 olduğu ve biyoloji öğretmen adaylarının eleştirel düşünebilme düzeylerinin yüksek olduğu tespit edilmiştir. Empati kurarak eleştirel düşünme eğilimine dair görüş sorusu için Genetiği Değiştirilmiş Ürünlere İlişkin Eleştirel Düşünme Dereceli Puanlama Anahtarının alt boyutlarından alınan puanlar "bilgi" boyutunda 10.1, "empati" boyutunda 2.6, "mantık" boyutunda ise 2.6'dır. Üç boyutun da dereceli puanlama anahtarına ait boyut orta değerlerinin üzerinde bir değere sahip olduğu görüşmüştür. 


\subsection{Biyoloji Öğretmen Adaylarının Eleştirel Düşünme ve Empati Kurarak Eleştirel Düşünme Düzeyleri Arasındaki Fark}

Biyoloji öğretmen adaylarının eleştirel düşünme düzeylerini ortaya çıkarmayı hedefleyen her iki görüş sorusu için betimsel olarak Genetiği Değiştirilmiş Ürünlere illişkin Eleştirel Düşünme Dereceli Puanlama Anahtarı ile belirlenen farkın istatistiksel olarak anlamlı olup olmadığını tespit etmek için başvurulan ilişkili örneklemler t-testi analizi Tablo ${ }^{5}$ te verilmiştir.

Tablo 5

Biyoloji Öğretmen Adaylarının Eleştirel Düşünme ve Empati Kurarak Eleştirel Düşünme Düzeylerine Yönelik Iliş̧kili Örneklemler T-Testi Sonuçları

\begin{tabular}{|c|c|c|c|c|c|c|}
\hline Ölçüm & $\mathbf{N}$ & $\overline{\boldsymbol{X}}$ & $S$ & sd & $t$ & $p$ \\
\hline $\begin{array}{l}\text { 1.Görüş Sorusu (Tarım arazilerinde genetiği değiştirilmiş } \\
\text { ürünlerin yetiştirilmesini onaylıyor musunuz? Bu } \\
\text { konudaki görüşlerinizi ve nedenlerini açıklayınız.) }\end{array}$ & 22 & 13.9 & 2.31 & & & \\
\hline $\begin{array}{l}\text { 2.Görüş Sorusu (Verimli bir araziniz olduğunu düşünün. } \\
\text { Kendi arazinizde genetiği değiştirilmiş ürünlerin } \\
\text { yetiştirilmesine onay verir miydiniz? Bu konudaki } \\
\text { görüşlerinizi ve nedenlerini açıklayınız.) }\end{array}$ & 22 & 15.3 & 1.78 & 21 & -2.9 & 0.008 \\
\hline
\end{tabular}

Tablo 5 'te verilen ilişkili örneklemler için t-testi analizi sonucunda empati kurarak eleştirel düşünme görüş sorusu lehine anlamlı $(\bar{X}=15.3)$ bir fark tespit edilmiştir $(t=-2.9$, $p<0.05)$. Bu sonuca göre empatik ifade eleştirel düşünme düzeyini arttırmada etkili olmuştur.

\subsection{Biyoloji Öğretmen Adaylarının Genetiği Değiştirilmiş Ürünlerle İlgili Karar Verme Durumlarının Dağılımları}

Araştırmada genetiği değiştirilmiş ürünlerin tarımsal uygulamalara dair eleştirel düşünme ve empati kurarak eleştirel düşünmeleri sonucu belirttikleri karar durumlarının dağılımlarına ilişkin betimsel istatistik sonuçları Tablo $6^{\prime}$ da sunulmuştur.

Tablo 6

Genetiği Değiştirilmiş Ürünlerin Tarımsal Uygulamalarına ilişskin Karar Verme Durumları

\begin{tabular}{|c|c|c|c|c|c|c|c|}
\hline & \multicolumn{7}{|c|}{ Eleştirel Düşünme Görüşlerine Göre Karar Verme Durum } \\
\hline \multicolumn{2}{|c|}{ Onay } & & Onay & & ret & Ret & \\
\hline$f$ & $\%$ & $\mathbf{f}$ & $\%$ & f & $\%$ & f & $\%$ \\
\hline -- & -- & 6 & 27.3 & 5 & 22.7 & 11 & 50 \\
\hline
\end{tabular}

Empati Kurarak Eleştirel Düşünme Görüşlerine Göre Karar Verme Durumları

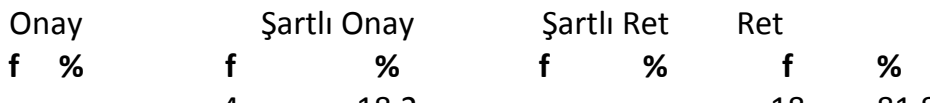

$\begin{array}{llllllll}-- & -- & 4 & 18.2 & -- & -- & 18 & 81.8\end{array}$

Tablo 6'ya göre, sosyobilimsel konuya dair genel olarak eleştirel düşünmeye sevk edecek birinci görüş sorusuna ilişkin karar verme durumunda, şartlı onaylama \%27.3 oranında, şartlı reddetme \%22.7 oranında ve reddetme \%50 şeklinde karşımıza çıkarken; öğretmen adaylarının eleştirel düşünme eğilimine empatik boyutun açık bir şekilde eklenmesi ile görüşlerde direkt onayın ve şartlı reddin bulunmadığı, şartlı onayın \%18.2, direkt reddin ise \%81.8 şeklinde değiştiği görülmektedir. Aşağıda öğretmen adaylarının görüşlerine ilişkin örnek ifadelere yer verilmiştir.

Eleştirel düşünme görüşlerine göre karar verme durumlarına ilişkin örnek ifadeler:

Direkt ret durumuna ilişkin ifade: 
Ö4: "Kolay yetişiyor, hızlı ürün veriyor ve her türlü böceğe dayanıklı diye genetiği değiştirilmiş ürünlerin yetiştirilmesini onaylamak demek, ben doğayı ve döngüsünü hiçe sayıyorum demektir."

Şartlı ret durumuna ilişkin ifade:

Ö9: " Çevresindeki tür çeşitliliğine ve yarattığı sağlık sorunları kesin olarak bilinmediğinden tarım arazilerinde genetiği değiştirilmiş ürünlerin yetiştirilmesini onaylamıyorum."

Şartlı onay durumuna ilişkin ifade:

Ö15: "...Genetiği değiştirilmiş ürünler yetiştiriliyorsa, o arazide genetiği değiştirilmemiş ürünlerin yetiştirilmemesi kaydıyla ve o arazide ürüne ilişkin tabela mevcutsa genetiği değiştirilmiş ürünlerin yetiştirilmesinde sorun görmüyorum."

Empati kurarak eleştirel düşünme görüşlerine göre karar verme durumlarına ilişkin örnek ifadeler:

Şartlı onay durumuna ilişkin ifade:

Ö1: "Ülkeyi kıtlık sarmış, nüfus hızla artmış veya bir savaş söz konusu ise kendi arazimde halkın zorunlu ihtiyaçlarını karşılamak adına arazimde genetiği değiştirilmiş ürün yetiştirebilirim."

Direkt ret durumuna ilişkin ifade:

Ö15: "Kendi verimli arazimde genetiği değiştirilmiş ürünleri yetiştirmezdim. Çünkü arazimi kullanabilmeyi uzun vadede düşünürdüm. Kendi arazimde yetişen ürünleri çocuğumun ve hatta onun çocuğunun doğal olarak tüketmesini isterdim."

Ayrıca Tablo 6'ya göre biyoloji öğretmen adaylarının, sosyobilimsel konudaki eleştirel ve empati kurarak eleştirel düşünme sorularına dair karar değişimlerine bakıldığında ise genetiği değiştirilmiş ürünlerle ilgili tarımsal uygulamalara karar verme durumunda eleştirel düşünmeye sevk eden soruya ait görüşlerdeki dağılımlara kıyasla, empati kurarak eleştirel düşünmeye sevk eden soruya ait görüşlerdeki dağılımlarda şartlı onayın \%9,1 oranında azalma, reddetmenin ise $\% 31,8$ oranında artış gösterdiği söylenebilir.

\section{TARTIŞMA}

Yapılan içerik analizlerine göre biyoloji öğretmen adaylarının genetiği değiştirilmiş ürünlerin tarımsal uygulamalarına ilişkin sosyobilimsel konusundaki her iki görüş sorusunun hukuk, ekonomi, ekoloji ve etik temalarına ilişkin kodların sayı ve içerik olarak çok farklılaşmadığı ancak eleştirel düşünme görüşlerine kıyasla empati kurarak eleştirel düşünme görüşlerindeki empati teması altında toplanan kodların arttığı ve öğretmen adaylarının daha detaylı şekilde değerlendirme yaparak sosyobilimsel konuyu kendisi, ailesi, toplum, hayvanlar ve tarım arazileri açılarından çok yönlü değerlendirdiği görülmektedir. Bununla birlikte temalar altındaki kodların her iki görüş sorusu açısından dağılımlarına bakıldığında, sadece hukuk ve ekonomi temalarındaki kodların eleştirel düşünme görüş sorusunda yüksek olduğu; ekoloji, etik ve empati temalarına ait kod dağılımlarının ise empati kurarak eleştirel düşünme görüş sorusunda oldukça yüksek olduğu görülmektedir. Nosich $(2012$, s.23) tarafından yapılan empatinin eleştirel düşünmenin merkezinde konumlandığını vurgusu çalışmamızın bulgularını destekler niteliktedir. Bu durum empati vurgusu ile desteklenmiş örnek ve soruların eleştirel düşünmeyi daha detaylı ve etkili bir biçimde yapmaya yardımcı olabileceği şeklinde yorumlanabilir.

Biyoloji öğretmen adaylarının her iki soruya dair belirttikleri görüşlerinin dereceli puanlama anahtarı ile nicelleştirilmesi sonucunda, eleştirel düşünme puan ortalamasının orta, ancak empati kurarak eleştirel düşünme ortalamasının yüksek bir değere sahip olduğu 
görülmektedir. Bu sonuca dayanarak empati kurmanın veya soruda yer alan empatik ifadelerin eleştirel düşünme düzeyini arttırdığı söylenebilir. Bu sonuçlar biyoloji öğretmen adaylarının herhangi bir konudaki eleştirel düşünme sürecinde empatinin devreye sokulmasıyla eleştirel düşünmelerinin nitelik olarak da artacağını düşündürmüştür. Nitekim literatürde yer alan çalışmaların bir kısmı lisans düzeyindeki öğrencilerde tartışmalı konulara ilişkin eleştirel düşünme becerilerinin arttııımasını (Doğanay, Akbulut-Taş ve Erden, 2007), bir kısmı ise empatik eğilimlerinin geliştirilmesini vurgulamaktadır (Acun Kapıkıran, 2009; Ekinci ve Aybek, 2010; Pala, 2008; Tutuk, Al ve Doğan, 2002).

Biyoloji öğretmen adaylarının genetiği değiştirilmiş ürünlerin tarımsal uygulamalarına ilişkin görüşlerinin dereceli puanlama anahtarı ile değerlendirilmesi sonucunda, empati kurarak eleştirel düşünmeye sevk eden görüş sorusunun toplam puan ve alt boyutlar (bilgi, empati ve mantık) açısından genel eleştirel düşünme görüş sorusundan alınan puanlara kıyasla daha yüksek olduğu tespit edilmiştir. Bu sonuçlara göre, biyoloji öğretmen adaylarının genetiği değiştirilmiş ürünlerin tarımsal uygulamalarına ilişkin sosyobilimsel konuda, empati kurarak eleştirel düşünmeye yönelik soruda daha derin değerlendirmelerde bulundukları söylenebilir.

Çalışma kapsamında iki soru arasında betimsel olarak belirlenen farkın anlamlılı̆ı istatistiksel olarak test edilmiş ve empati kurarak eleştirel düşünme görüş sorusu lehine anlamlı bir fark tespit edilmiştir. Bu çarpıcı bulgu, empati ile desteklenen eleştirel düşünme sorularının veya örneklerinin biyoloji öğretmeni adaylarının konuyu daha iyi içselleştirmelerini ve derin biçimde sorgulayarak daha nitelikli biçimde eleştirel düşünmelerini sağlayabileceği şeklinde yorumlanabilir. Nitekim Çakırlar-Altuntaş, Yılmaz ve Turan (2016) tarafından yapılan çalışmada biyoloji öğretmen adaylarının eleştirel düşünme eğilimleri ile empatik eğilimleri arasında pozitif yönlü ve orta düzeyde korelasyonun varlığı tespit edilmiştir. Ekinci ve Aybek (2010) tarafından yapılan çalışmada da eleştirel düşünme ile empatik eğilim arasında pozitif yönde ve anlamlı bir ilişki bildirilmiştir. Bir başka deyişle empatik eğilim arttıkça eleştirel düşünme eğilimi de artış göstermektedir ki bu çalışmalar araştırmamızın sonuçlarını da destekler niteliktedir.

Çalışmada içerik analizi ile elde edilen empati kurarak eleştirel düşünme görüş sorusunda yer alan kod ve frekans dağııımlarının yüksek düzeyde olması ve nicel olarak dereceli puanlama anahtarı ile elde edilen yüksek düzeyin, empati kurarak eleştirel düşünme görüş sorusu lehine sonuçlar vermesi birbirini desteklemektedir. Çalışmada empati kurmanın eleştirel düşünme üzerinde nitel ve nicel olarak olumlu katkıda bulunacak sonuçlar sunması, biyoloji öğretmen adaylarının empati yetenekleri desteklendikçe eleştirel düşünmelerinin de güçleneceği şeklinde yorumlanabilir. Çakırlar-Altuntaş, Yılmaz ve Turan (2016) tarafından yapılan çalışmada da biyoloji öğretmen adaylarının empatik eğilimlerinin eleştirel düşünme eğilimlerini tek başına \%26 oranında tahmin ettiği tespit edilmiştir. Araştırmacıların elde ettiği yüksek tahmin oranı, çalışmamızın birbirini destekleyen nitel ve nicel sonuçları ile uyumludur.

Biyoloji öğretmen adaylarının genetiği değiştirilmiş ürünlerin tarımsal uygulamalarına ilişkin karar verme durumlarında genel eleştirel düşünme sorusu bağlamındaki görüşlere kıyasla empati kurarak eleştirel düşünme sorusu bağlamındaki görüşlerde şartlı onayın \%9.1 oranında azalma, reddetmenin ise \%31.8 oranında artı̧̧ gösterdiği tespit edilmiştir Bu sonuçlar, Nosich'in (2012, s.23) ifade ettiği gibi eleştirel düşünmenin merkezinde konumlanan empatinin önemine dikkati çekmektedir. Öyle ki, sonuçlarımız biyoloji öğretmeni adaylarında empatinin eleştirel düşünme sırasında açık bir şekilde ortaya konmasının görüşlerimizi değiştirebileceğini ve eleştirel düşünme çerçevemizi geliştirip genişleterek, görüşlerimizi derinleştirmeye katkı sağlayacağını gösterebilir. Bu çalışmada, empati kurarak eleştirel bir bakış açısı sergilendiğinde bireylerin hem kendi görüşlerini hem de karşı tarafın görüşlerini, kendisini diğerlerinin yerine koyarak, olumlu ve olumsuz yönlerini tartışıp, benmerkezcilikten uzaklaşarak değerlendirdiğinde daha derin sorgulamalar yaptıkları, daha geniş sonuçlara ulaştıkları ve bu 
görüşler doğrultusunda genetiği değiştirilmiş ürünlerin tarımsal uygulamalarında karar verme durumlarına ilişkin onay oranlarının azaldığı görülmüştür. Çalışmanın bu çarpıcı sonucu, biyoloji öğretmeni adaylarında empati kurarak eleştirel düşünmenin, bir başka deyişle değerlendirdiği konuyu kendisiyle ilişkili görmenin, daha derin, detaylı ve gerekçeli düşünmeyi desteklediği; sosyobilimsel konuyla ilgili görüşlerini daha açık hale getirdiği ve onaylama davranışını değiştirebileceği şeklinde yorumlanabilir. Bu bağlamda konuyu kendi hayatıyla ilişkilendirme düzeyi arttıkça eleştirel düşünmenin de güçleneceği ve karar verme davranışlarını da etkileyebileceği düşünülebilir. Yılmaz ve Demirhan (2014) gen değişiklikleri uygulamalarına ilişkin kararsız ve onay vermede çekingen bakış açılarının netleşmesinde konuyla kişisel olarak ilgilenmenin ve risk algısı düzeyinin etkili olduğunu belirtmektedir. Gerçekten de gen teknolojisine ilişkin kuşkucu ve kararsız olan kamuoyu tutumunun onay verme görüşünde riskfayda algılarının etkili olduğu (Pfister, Böhm ve Jungerman, 2000; Saba, Rosati ve Vassallo 2000; Siegrist 2000) ve kişisel ilgi yüksekse, konuların daha detaylı incelenip, onay sürecinin etkileneceği bildirilmektedir (Petty, Brinol ve Tormala, 2002). Bu sonuçlar, araştırmamızda elde edilen sonuçları desteklemekte ve konuyla kişisel olarak ilgilenme ve kendisiyle ilişkili görmenin konuyu daha derin biçimde ele almayı sağlayacağını ve onaylama davranışı üzerinde etkili olabileceğini düşündürmektedir.

\section{SONUÇ VE ÖNERILER}

Yapılan araştırmanın sonuçlarına göre, biyoloji öğretmen adaylarına sosyobilimsel konuda eleştirel değerlendirme yaptırmak amacıyla sorulan açık uçlu görüş sorularının, olayı kendimizle ilişkilendirdiğimiz empatik vurgular ile desteklendiğinde, farklı güçte ve yönde eleştirel değerlendirmeler yapmayı sağladığı görülmüştür.

Araştırma, biyoloji öğretmen adaylarının genetiği değiştirilmiş ürünlerin tarımsal uygulamalarına ilişkin olarak genel eleştirel düşünme ve empati kurarak eleştirel düşünme görüş sorularında aynı temalara (hukuk, ekonomi, ekoloji, etik ve empati) yer verdikleri görülmüştür. Ancak empati vurgusunun daha güçlü yapıldığı empati kurarak eleştirel düşünme sorusuna yönelik görüşlerde kendilerini durumun merkezine alarak sosyobilimsel konunun olumlu ve olumsuz yönlerini daha derin biçimde ve eleştirel olarak değerlendirilebildikleri, kodların ise çeşit ve oran açısından arttığı tespit edilmiştir. Araştırmada elde edilen diğer önemli bir sonuca göre, biyoloji öğretmen adaylarının sosyobilimsel bir konu kapsamındaki karar verme durumlarının kendi hayatları ile ilişkili empatik sorular yöneltildiğinde değişiyor olması, empatik vurguların kararlarda da değişime neden olmasını göstermesi açısından dikkate değerdir.

Biyoloji öğretmen adaylarında genel eleştirel düşünme görüş sorusundaki ortalamalarının orta; empati kurarak eleştirel düşünme görüş sorusundaki ortalamanın ise yüksek düzeyde olduğu belirlenmiştir. Ayrıca her iki puan arasındaki farkın istatistiki olarak da anlamlı olduğunun tespit edilmesi araştırmanın çarpıcı sonuçlarındandır. Diğer bir söylemle biyoloji öğretmen adaylarının sosyobilimsel konudaki görüşlerinin oluşumunda, eleştirel düşünmeye dair sorulan soruların empati vurgusu ile yapılmasının, eleştirel düşünmeyi desteklediği nitel ve nicel yollarla incelenen araştırma soruları çerçevesinde ortaya konmuştur.

Bu araştırmanın sonuçlarına dayanarak, biyoloji öğretmenleri yetiştirilirken eleştirel düşünme becerilerinin gelişmesi adına lisans derslerinde argümantasyon gibi araştırmasorgulamaya dayalı öğretim yöntemlerinin kullanılması ve bireylerin hayatlarına ilişkin unsurlar barındıran empatik soruların informal ve ahlaki muhakeme becerilerini arttıracak şekilde derslere eklenmesi önerilmektedir. Bunların yanısıra örneklem sayısı ve çeşitliliği arttırılarak, empatik eğilimin toplumda ikilem yaratan birçok sosyobilimsel konudaki eleştirel düşünme ve 
karar verme davranışı üzerindeki etkilerinin incelendiği nitel ve nicel çalışmaların yapılarak, sonuçların karşılaştırılması ve genişletilmesi de öneriler arasında yer alabilir.

\section{KAYNAKLAR}

Acun Kapıkıran, N. (2009). Öğretmen adaylarının empatik eğilim ve kendini ayarlama açısından incelenmesi. Pamukkale Üniversitesi Eğitim Fakültesi Dergisi, 26, 81-91.

Albe, V. (2008). Students' positions and considerations of scientific evidence about a controversial socio-scientific issue. Science \& Education, 17(8-9), 805-827.

Büyüköztürk, Ş. (2014). Sosyal bilimler için veri analizi el kitabı (19.Baskı). Pegem Akademi

Cotton, K. (1991). Teaching thinking skills (pp. 1-19). Northwest Regional Educational Laboratory, School Improvement Program.

Creswell, J. W. \& Garrett, A. L. (2008). The "movement" of mixed methods research and the role of educators. South African Journal of Education, 28(3), 321-333.

Cüceloğlu, D. (1995). lyi düşün doğru karar ver. İstanbul: Sistem Yayıncılık.

Çakırlar-Altuntaş, E., Yılmaz, M. \& Turan, S. L. (2016). Biyoloji öğretmen adaylarının eleştirel düşünme eğilimlerinin incelenmesi. 12. Ulusal Fen Bilimleri ve Matematik Eğitimi Kongresi, 28-30 Eylül, Karadeniz Teknik Üniversitesi, Trabzon.

Demirel, Ö. (2012). Eğitimde program geliştirme kuramdan uygulamaya (18.Baskı). Ankara: Pegem Akademi Yayıncılık.

Doğanay, A., Akbulut-Taş, M. \& Erden, Ş. (2007). Üniversite öğrencilerinin bir güncel tartışmalı konu bağlamında eleştirel düşünme becerilerinin değerlendirilmesi. Kuram ve Uygulamada Eğitim Yönetimi, 52, 511-546.

Dökmen, Ü. (2005). Iletişim çatışmaları ve empati (31. Baskı). İstanbul: Sistem Yayıncılık.

Eastwood, J.L., Sadler, T.D., Zeidler, D.L., Lewis, A., Amiri, L. \& Applebaum, S. (2012). Contextualizing nature of science instruction in socioscientific issues. Internationel Journal of Science Education, 34(15), 2289-2315.

Ekinci, Ö. \& Aybek, B. (2010). Öğretmen adaylarının empatik ve eleştirel düşünme eğilimlerinin incelenmesi. Ilköğretim Online, 9(2), 816-827.

Epstein, R. L. (1999). Critical thinking. Belmont: Wadsworth Publishing Company.

Kolsto, S.D. (2006). Patterns in students' argumentation confronted with a risk-focused socioscientific issue. International Journal of Science Education, 28(14), 1689- 1716.

Kökdemir, D. (2003). Belirsizlik durumlarında karar verme ve problem çözme. Yayınlanmış Doktora Tezi. Ankara Üniversitesi, Sosyal Bilimler Enstitüsü, Ankara.

Kutlu, H., Doğan, C. D. \& Karakaya, İ. (2009). Öğrenci başarısının belirlenmesi performansa ve portfolyoya dayalı durum belirleme. Ankara: Pegem Akademi.

Lee, H., Abd-El-Khalick, F. \& Choi, K. (2006). Korean science teachers' perceptions of the introduction of socio-scientific issues into the science curriculum. Canadian Journal of Science, Mathematics and Technology Education, 6(2), 97-117.

Milli Eğitim Bakanlığı (MEB), (2016). Ortaöğretim Öğretim Programları, Talim ve Terbiye Kurulu Başkanlığı, Ankara. 
Miles, M. B. \& Huberman, A. M. (1994). Qualitative data analysis: An expanded source book. California: Sage Publications.

Gardner, D. P., Larsen, Y. W., Baker, W., Campbell, A., \& Crosby, E. A. (1983). A nation at risk: The imperative for educational reform (p. 65). United States Department of Education.

Norris, S. P. (1985). Synthesis of research on critical thinking. Educational Leadership, 8, 40-45.

Nosich, M.G. (2012). Eleştirel düşünme ve disiplinler arası eleştirel düşünme rehberi (B. Aybek, Çev.). Ankara: Anı Yayıncılık.

Pala, A. (2008). Öğretmen adaylarııı empati kurma düzeyleri üzerine bir araştırma. Pamukkale Üniversitesi Eğitim Fakültesi Dergisi, 23, 13-23.

Paul, R.W. (1991). Staff development for critical thinking: Lesson plan remodelling as the strategy. In A.L.Costa (Ed.). Developing Minds (A Reseource Book For Teaching). Alexandria, Virginia: Revised Education.

Paul, R. W. (1984). Critical thinking fundamental to education for a free society. Educational Leadership, 1, 5-14.

Petty, R.E., Brinol, P. \& Tormala, Z.L. (2002). Thought confidence as a determinant of persuasion: Theself validation hypothesis. Journal of Personality and Social Psychology, 82(5), 722-741.

Pfister H.R., Böhm, G. \& Jungermann, H., (2000). The cognitive representation of genetic engineering: Knowledge and evaluations. New Genetics and Society, 19(3), 295-316.

Saba, A., Rosati, S. \& Vassallo, M., (2000). Biotechnology in agriculture: perceived risks, benefits and attitudes in Italy. British Food Journal, 102(2), 114-121.

Sadler, T. D. (2003). Informal reasoning regarding SSI: Their influence on morality and content knowledge. Published Doctoral Dissertation. University of Sout Florida.

Sadler, T.D. (2004). Informal reasoning regarding socio scientific issues: A critical review of literature. Journal of Research in Science Teaching, 4, 513-536.

Sadler, T.D., \&Zeidler, D.L. (2004). Themorality of socio-scientific issues: Construal and resolution of genetic engineering dilemmas. Science Education, 88, 4-27.

Siegrist, M. (2000). The influence of trust and perceptions of risks and benefits on the acceptance of GT. Risk Analysis, 20(2), 195-203.

Topçu, M.S. (2015). Sosyobilimsel konular ve öğretimi. Ankara: Pegem Akademi.

Tutuk, A., Al, D. \& Doğan, S. (2002). Hemşirelik öğrencilerinin iletişim becerisi ve empati düzeylerinin belirlenmesi. C. Ü. Hemşirelik Yüksek Okulu Dergisi, 6(2), 36.

Walsh, D. \& Paul, R. (1988). The goal of critical thinking: From educational ideal to educational reality. Washington D.C.: American Federation of Teachers.

Yıldırım, A. \& Şimşek, H. (2011). Sosyal bilimlerde nitel araştırma yöntemleri (8.Baskı). Ankara: Seçkin Yayıncılık.

Yılmaz, M. \& Demirhan, H. (2014). Variables predicting prospective biology teachers' acceptance perceptions regarding gene technology. European Journal of Science and Mathematics Education, 2(3), 147-154. 


\section{SUMMARY}

The reason for including the socio-scientific issues related to sciences subject contents to education is stated as socializing the individuals who have responsibility and the ability of thinking critically. It is expected that the critical thinking ability of individuals contribute them to perceive the subjects with social dilemma and analyse these subjects. Empathy which is an integral part of critical thinking (Nosich,2012, s.23) is substantially important in the development of individuals' critical thinking ability.

It is stated that the teachers who can think critically play an important role in that students sufficiently comprehend the socio-scientific issues they often come across in daily life, perceive the actions and processes underlying the decisions related to these subjects and in their decision making states (Albe, 2008; Kolsto, 2006). Based on these statements, this research aims to investigate the views of prospective biology teachers about critical thinking related to socioscientific issues regarding agricultural applications of genetically modified products and asking the same question developing empathy, their critical thinkings and critical thinkings by developing empathy, whether there is a significant difference between these levels and their decision making states related to the subject. The conclusions and suggestions of the study are expected to contribute to bring up students with high level thinking abilities, who are inquisitive about socioscientific issues as well as biology teachers.

The study group of the research using mixed method consists of 22 prospective teachers studying in the Department of Biology in a state university in Spring Term 2015-2016. The qualitative data collection form used in this research consistedof two open ended questionsabout the socioscientific issues of prospective biology teachers'agricultural applications of genetically modified products. In the data collection form, the first question was critical thinking oriented and as follows: "Do you agree to cultivate genetically modified products in agricultural lands? Explain your views on this subject and the reasons for them." The second question was critical thinking by developing empathy oriented and as follows: "Suppose that you have a fertile land. Would you agree that genetically modified products are cultivated on your land? Explain your views on this subject and the reasons for them." In the analysis of the collected data, content analysis was primarily used for the views. The levels of critical thinking were determined by rubrics which were developed by researchers and tested in terms of validity and reliability. T-test was used to determine whether there is a significant difference between these two levels. Descriptive statistics was used for the decision making states of prospective teachers.

As a result, it is found that the average of prospective biology teachers about view of general critical thinking is at medium level while view of general critical thinking by developing empathy is at high level. In addition, finding that the difference between two levels is statistically significant is among the important conclusions of this research. It is found that in both questions related to the agricultural applications of genetically modified products the same themes (law, economy, ecology, ethics and empathy) were discussed, however, in the views responding the critical thinking by developing empathy questions in which empathy was emphasized more strongly, prospective teachers evaluated the positive and negative sides of the socioscientific issues more deeply and critically by self-centring themselves, the codes under the themes increased in variety and proportion. The finding of the research related to the chance in decision making states of the prospective biology teachers regarding the mentioned socioscientific issues when the emphatic questions related to their own lives were asked is remarkable in terms of showing that emphatic emphasis causes change in decisions and makes critical thinking deeper and more detailed. 